\title{
WORKMEN'S COMPENSATION AWARDS FOR RECREATIONAL INJURIES
}

An injured employee is entitled to a workmen's compensation award if his injury fits within the statutory formula, "arising out of and in the course of employment." Where the work-connection is not obvious, the courts have developed categories of fact situations, isolating some one or more factors to bridge the gap to the statutory "course of employment."2 One relatively new situation, which has given the courts some difficulty, involves injuries sustained by the employee while engaging in a recreational program which is in some degree supported by the employer. Two recent cases coming to contradictory results well illustrate the borderline recreational program problem.

In Jewel Tea Co. v. Industrial Commission, ${ }^{3}$ where compensation was awarded, the claimant employee was injured while participating in an intra-company league softball game in a public park after working hours. Originally the employees themselves organized an informal sports program. ${ }^{4}$ Later, schedules and rules were arranged by team managers and the company personnel chief at a company-financed dinner meeting. The company provided trophies, balls and bats, and T-shirts bearing the Jewel emblem. Spectators were not accommodated at games, nor was admission charged, though some friends and relatives of the players attended the games. Information about the games was disseminated through company publications and the company radio station. Teams were named after district managers. Here claimant went out for the team after a chiding comment by the employee selected by the district manager to solicit players and to manage the team.

In granting the award the court held that there was significant benefit to the employer in the form of increased good will and esprit de corps among employees, and improved employer-employee relations, resulting from the recreational contacts. In addition the T-shirts supplied by the company put its name before the public so as to secure advertising benefits. Although the employees were not

1 Forty states and the District of Columbia use this formula for determining compensability of injuries. Eight states, North Dakota, Pennsylvania, Texas, Utah, Washington, West Virginia, Wisconsin and Wyoming, employ minor variations of the formula. 1 Larson, Workmen's Compensation Law $\$ \$ 6,10$ (1952).

2 Thus in the "personal comfort" cases, an employee may be compensated for an injury incurred while smoking, eating, resting, etc., on the theory that such acts, though personal to the employee, are necessarily contemplated by the employer as incidental to the service. E.g., Spencer v. Chesapeake Paperboard Co., 186 Md. 522, 47 A. 2d 385 (1946); Elliott v. Industrial Accident Comm'n, 21 Cal. 2d 281, 131 P. 2d 521 (1942). In the "horseplay" cases an employee may be compensated where his injury resulted from good-natured roughhouse of other employees, on the theory that such diversions are reasonably to be expected in an employment situation, and the consequent risks are incidental to the employment. E.g., Pacific Employers Ins. Co. v. Industrial Accident Comm'n, 26 Cal. 2d 286, 158 P. 2d 9 (1945); Leonbruno v. Champlain Silk Mills, 229 N.Y. 470, 128 N.E. 711 (1920).

36 Ill. 2d 304, 128 N.E. 2d 699 (1955).

- Brief for Defendant in Error at 6. 
required to participate, subtle pressures were exerted-claimant could well have been concerned with his standing with the district manager, and thereby his chance for advancement, if he refused to participate.

On similar facts recovery was denied the injured employee in Wilson $v$. General Motors Corp. ${ }^{5}$ Here the employees had organized a baseball league on their own initiative. A salaried foreman supervised the league and distributed company-purchased equipment and uniforms bearing the letters " $M$ \& $A$ " (signifying Motor and Axle Division). There was generally no outside attendance at games. The company allowed meetings of team managers during working hours. Recovery was denied on the ground that there was no direct business advantage or benefit to the company from employee participation in such contests. Employer support was seen as a gratuitous contribution, for,

too tenuous and ephemeral is the possibility that such participation might perhaps indirectly benefit the employer by improving the workers' morale or health or by fostering employee good will. ${ }^{6}$

In dissent Judge Conway argued that the recreational activity was promoted and encouraged by the employer and resulted in a business benefit to him in terms of better employer-employee relations. Furthermore the subordinate position of the employee caused a superior's mere suggestion of participation to assume connotations of compulsion.

These cases indicate the "work-connection" factors which the courts have been looking for in deciding the recreational program cases. First there is the theory that where participation is in some degree compulsory, the employer has extended the course of employment to include the recreational program. Second there is the belief that because the employer's motivation in establishing or supporting the program is probably to gain a business benefit, the employer should bear the risk of injuries sustained by the participants.

Generally courts have used the compulsion criterion to include degrees ranging from required attendance to the mere fact of employer sponsorship in the context of the employment relationship..$^{7}$ Where actual compulsion is

$$
5298 \text { N.Y. } 468,84 \text { N.E. } 2 \text { d } 781 \text { (1949). } \quad \text { 'Ibid., at 473, } 784 .
$$

7 The employer has been held to enlarge the course of employment where he has required the employee to participate in the recreational activity. Salt Lake City v. Industrial Comm'n, 104 Utah 436, 140 P. 2d 644 (1943) (fireman injured while playing handball where the employer city required the men to take exercise); Huber v. Eagle Stationery Corp., 254 App. Div: 788, 4 N.Y.S. 2d 272 (3d Dep't, 1938) (decedent employee required by employer to supervise and manage baseball team). Similarly injuries are compensable where participation was strongly urged and punitive measures taken for failure to comply, Stakonis v. United Advertising Co., 110 Conn. 384, 148 Atl. 334 (1930) (employee to be deprived of day's wages if he did not attend annual company picnic), or where participation was strongly urged and attendance checked. Kelly v. Hackensack Water Co., 10 N.J. Super. 528, 77 A. 2d 467 (1950); Miller v. Keystone Appliances, $133 \mathrm{~Pa}$. Super. 354, 2 A. 2d 508 (1938). Compulsion has been extended to include the situation where the employer makes it known that the employees are "expected" to attend and, although no punitive measures are involved, refusal by the employee would clearly prejudice his position with his employer. Linderman v. Cownie Furs, 234 Iowa 708, 
present there is clearly enough affirmative employer action to bring the activity within the literal meaning of course of employment. ${ }^{8}$ But literal compulsion is rarely a factor in the organized recreation program. The experts now discourage management paternalism or compulsion because it tends to defeat the purposes of the program. ${ }^{9}$ Employee interest and participation are increased when the administration of the program is in the hands of the employees themselves. ${ }^{10}$

As recreational programs have been framed to avoid connotations of compulsion, courts have broadened "compulsion" to include situations which are hardly within the ordinary meaning of the term. Judge Conway in his dissent in the Wilson case went to the extreme in declaring that a suggestion of participation in an employer-sponsored recreational activity is compulsion enough in the framework of an employee-employer relationship. According to the reasoning of the dissent, compulsion is actually the subtle pressure of the employment situation, which constrains an employee to do nothing, no matter how remote, to prejudice his position.

Except for the cases where the employer pressure to participate is clear, it is doubtful that the compulsion factor is a useful test for liability in these cases. If the recreation program is successful the employees will bring pressure on their co-workers to participate which in many cases will be indistinguishable from employer-instigated pressure. If the employer is being held liable solely because he has extended the course of employment through his compulsion, he should not be liable if the employee was "compelled" to participate by pressure spontaneous in the employee group. Difficult if not insoluble questions will thus be presented in deciding whether a particular employee's chiding comment had its origins in the esprit de corps of the employees or in the employer's sponsorship.

Even assuming that an employee's comment stems from the compulsion inherent in employer support, this compulsion can never in the borderline cases be divorced from the extent of employer support and encouragement of the activity. An employee will participate voluntarily for what is clearly a management-encouraged program. He may know of no direct prejudice for failure to participate; but he understands that advantages may accrue to the man who

13 N.W. 2d 677 (1944) (spurning invitation for trip would reflect on salesman's loyalty); Kelly v. Ochiltree Electric Co., $125 \mathrm{~Pa}$. Super. 161, 190 Atl. 166 (1937) (unfavorable impression would be left with employer if employee did not go on trip); Stockley v. School District, 231 Mich. 523, 204 N.W. 715 (1925) (refusal to go to teachers' institute would reflect on teacher's professional standing).

${ }^{8}$ E.g., Salt Lake City v. Industrial Comm'n, 104 Utah 436, 140 P. $2 d 644$ (1943).

9 National Recreation Association, The Do's and Don'ts of Employee Recreation, 10 Supervision No. 6 (June, 1948) 9.

10 "[U]pon condition of mandatory attendance . . . it would be human for the employees to resent and to resist the obviously contrived bounty of the employer, and the benefits to the employer and employees reasonably would be less substantial." Kelly v. Hackensack Water Co., 10 N.J. Super. 528, 536, 77 A. 2d 467, 471 (1950). 
shows company "spirit." Compulsion in this context does not exist unless and until the employer extends enough support and encouragement to an activity to constrain an employee to feel that it is in a real sense a part of his employment, so that his participation has a direct bearing on his job situation.

A more usable test of liability in the borderline cases can be developed from the theory that the employer should be liable if his purpose in extending support and encouragement to the program was to gain a business benefit. As illustrated by the Wilson case some courts bave interpreted the "benefit" phrase narrowly, limiting it to include only clearly recognizable financial benefit.". Hidden in some of the cases, however, is the idea that the employer benefits in an intangible sense; that the recreational activities bring returns in terms of improved health and morale of employees, and improved employee-employer relations. As in the Wilson case, however, recovery has generally been denied where morale benefit alone, without distinct monetary or advertising benefit, is shown. ${ }^{12}$

The initial judicial reluctance to recognize increased employee morale as a business benefit is not difficult to understand. The history of recreation programs shows that they frequently originated spontaneously with the employees and that the first contributions of the employer were motivated more by good will than by any precise notions of benefit to the business concern. ${ }^{13}$ Subsequent

II Where the employer encouraged and organized competitive sports and pocketed the receipts from a soccer game, the injured employee was allowed to recover. Holst v. N.Y. Stock Exchange, 252 App. Div. 233, 299 N.Y. Supp. 255 (3d Dep't, 1937). Recovery is granted where the recreational activity is a recognized part of a business scheme to increase sales. Linderman v. Cownie Furs, 234 Iowa 708, 13 N.W. 2d 677 (1944) (fishing trip as a reward for, and a means of stimulating sales efforts); Kelly v. Ochiltree Electric Co., 125 Pa. Super. 161, 190 Atl. 166 (1937) (convention trip for purpose of improving employer's sales organization). Where teams were organized to advertise the employer's name and business, or where the company exploited the publicity value of games in advertising or cementing public good-will, recovery has been allowed. Le Bar v. Ewald Bros. Dairy, 217 Minn. 16, 13 N.W. 2 d 729 (1944); Federal Mutual Liability Insurance Co. v. Industrial Accident Comm'n, 90 Cal. App. 357, 265 Pac. 858 (1928). Where recovery has been granted on the basis of advertising benefit resulting from employer-supplied uniforms displaying the company name, it has been shown that spectators were invited to and did attend the games. Fishman v. Lafayette Radio Corp., 275 App. Div. 876,89 N.Y.S. 2d 563 (3d Dep't, 1949). In the Jewel case T-shirts displayed the company name, but in light of the fact that spectators other than friends and relatives of the players were neither solicited nor accommodated at games, it is more likely that the shirts were used to promote team and company spirit, rather than to secure advertising benefit. Compare the Wilson case, discussed in text at $\mathrm{p} .329$ supra, where uniforms bore the emblem " $M \& \mathrm{~A}$ " and outsiders were not present. There the court could see no advertising benefit. The difference of wording on uniforms should be of little significance. The test of advertising benefit should be whether outsiders are actively encouraged to attend games.

12 Padula v. Royal Plating \& Polishing Co., 14 N.J. Super. 603, 82 A. 2d 225 (1951); Leventhal v. Wright Aeronautical Corp., 25 N.J. Misc. 154, 51 A. $2 \mathrm{~d} 237$ (1946); Industrial Comm'n v. Murphy, 102 Colo. 59, 76 P. 2d 741 (1938); Porowski v. American Can Co., 15 N.J. Misc. 316, 191 Atl. 296 (1937); Clark v. Chrysler Corp., 276 Mich. 24, 267 N.W. 589 (1936). Contra: Ott v. Industrial Commission, 83 Ohio App. 13, 82 N.E. 2d 137 (1948).

13 "In many instances action has preceded determination of the long-range goal of the company." National Industrial Conference Board, Employee Recreation Activities, Studies in 
study and experience showed that recreation programs were in fact beneficial to the concern, in improving company spirit, reducing employee turn-over, and generally improving labor relations. ${ }^{14}$ Presumably the general realization of this by industrial management experts has had its impact on the employer's motivation in continuing to support recreation programs. Perhaps in an earlier day courts were justified in presuming that the employer's intention was gratuitous. This is, as the Jewel court recognized, no longer a valid presumption..$^{15}$ Even granting the practical difficulty of rebutting it, the presumption must be that the employer's support of a recreational program is motivated by the belief that in the end it will benefit the company more than it costs..$^{16}$

Judicial reluctance to compensate on the basis of morale benefit may also have been influenced by the belief that imposition of legal liability might result in curtailment of employer support of recreation programs. ${ }^{17}$ Thus in Wilson $v$. General Motors Corp. the court declared,

Personnel Policy No. 102 (1949) 5. Employee recreation activities of 264 plants and offices were surveyed for this report. The companies studied ranged from those with fewer than 500 employees to those with over 5000 employees, in manufacturing industries, banks, public utilities, transportation and wholesale and retail industries.

14 Ibid., at 48; Boak, Letting Employees Run the Recreation Program, 103 Factory Management and Maintenance No. 12 (December, 1945) 118, 120.

${ }^{15}$ The lag in the courts is understandable even as late as 1938. See Industrial Comm'n v. Murphy, 102 Colo. 59,76 P. 2d 741 (1938). When it appears in 1953, see McFarland v. St. Louis Car Co., 262 S.W. 2d 344 (Mo., 1953) or in 1949 in the comprehensive Wilson opinion, 298 N.Y. $468,473,84$ N.E. $2 d$ 781, 784 (1949), it would seem that courts are being mechanical in their analysis.

${ }^{16}$ The presumption of benefit has long been applied in the tax field. As early as 1925 an employer was allowed to deduct a contribution to the local school (attended almost entirely by children of his employees) as an "ordinary and necessary" business expense on the ground that the contribution contemplated a resulting advantage in decreased employee turnover. Holt-Granite Mills Co., 1 B.T.A. 1246 (1925). Accord: Superior Pocahontas Coal Co., 7 B.T.A. 380 (1927) (business deduction allowed for contribution to church frequented almost entirely by employees). But cf. Climax Spinning Co., 8 B.T.A. 970 (1927) (deduction for contribution to village baseball team, where five local mills paid expenses, disallowed as ordinary and necessary business expense. The business benefit here was more remote where a village team supported by several employers was involved. It might be said that the contribution was prompted by civic pride rather than as a business expense). See National Yarn Mills, 10 B.T.A. 1102 (1928). A business expense is valid and deductible as an "ordinary and necessary" business expense in carrying on a trade or business where incurred to secure intangible morale benefits for the enterprise. Slaymaker Lock Co., 18 T.C. 1001 (1952) (company purchased and improved property and converted house into lodge for employee recreation. Deduction allowed on ground that expense was incurred to decrease labor turnover); Robert S. LeSage, 6 T.C.M. 1263 (1947) (expenses of annual Christmas party deductible where the party was to improve business contacts and increase employee morale); H. H. Bowman, 16 B.T.A. 1157 (1929); Popular Dry Goods Co., 6 B.T.A. 78 (1927). Different policies underlie the use of the benefit criterion in the tax field. Though less need be shown to imply benefit for tax deduction purposes than to impose workmen's compensation liability, the presumption employed is analogous.

${ }^{17}$ See Industrial Commission v. Murphy, 102 Colo. 59, 76 P. $2 d 741$ (1938). 
[w]ere the courts to impose such a duty because the employer gave a modicum of encouragement... the employer might, in his own self-interest, seek to escape the burden by withholding all aid and support. ${ }^{18}$

This conclusion stems from the mistaken notion that morale benefit is not real. It is more likely that in situations where liability is imposed, the extent of benefit received will be sufficiently compelling to persuade the employer to continue the program. If the benefit is great enough liability for injuries may well be considered by the employer as one of the risks of the benefit bargained for. ${ }^{19}$

The difficulty in these borderline recreation program cases stems largely from the fact that while the employer gains some benefit from these programs, the employees are the direct beneficiaries and the morale benefit which the employer receives is only a reflection of the employees' gain. Even in workmen's compensation cases, the employer should not be liable for any injury which the employee sustains in the course of doing something which, while it may benefit the employer indirectly, is primarily for the employee's own well-being. The work-connecting factor in these cases is the employer's support by which he intends to gain a business benefit. Absent this intent, as reflected in the support, the benefit which the employer receives will not lead to compensation. ${ }^{20}$ In a workmen's compensation context it is not unfair to attach legal liability to activity through which the employer seeks a business gain.

Granting the validity of increased morale as a business benefit for compensation purposes, the difficult issue, raised in the Wilson and $J$ ewel cases, and which will trouble the courts in the future, centers on the extent of employer planning,

${ }^{18} 298$ N.Y. 468, 476, 84 N.E. 2d 781, 786 (1949).

${ }^{10}$ Imposition of liability may in some instances lead to increased safety precautions. It is also worth noting that the employer can deduct workmen's compensation awards as an ordinary and necessary expense of doing business.

${ }^{20}$ Use of the morale benefit theory as a basis of liability has also been criticized on the ground that the employees' participation in any recreational activity will benefit the employer. If followed this theory would entitle the employee to an award if he was injured while playing with his children. Consult 1 Larson, Workmen's Compensation Law $\$ 22.30$ (1952). This objection erroneously assumes that it is the fact of benefit to the employer rather than the employer's intention to gain a business benefit by supporting a recreation program which is crucial. Thus in Congdon v. Klett, 307 N.Y. 218, 120 N.E. 2d 796 (1954), compensation was denied an employee injured while using his employer's swimming pool after working hours. The employer had built the pool in the rear of the building housing both his residence and his business and allowed his two employees to use it during off hours. The employer "benefited" from his employee's activities but the support he gave was not enough to raise a presumption of intent to benefit. Similarly in State Y.M.C.A. v. Industrial Comm'n, 235 Wis. 161, 292 N.W. 324 (1940), a counselor at employer's summer camp was denied recovery for an injury sustained while using the camp's recreational facilities in his free time, though on call for emergency needs. The employer gave no active support, but rather passively acquiesced in claimant's activity. Although the case appears correctly decided on the narrow point of benefit (the activity was not directly stimulated or encouraged by the employer with an eye towards securing increased employee morale) its conclusion is of doubtful soundness. Under the circumstances, a summer camp situation where the employee is confined to the premises and on call at all times, it is surprising that compensation was not granted on a theory analogous to that used in the lunch-hour cases. Consult authorities cited note 25 infra. 
contribution, encouragement and control which will be necessary for a holding that the employer sought benefit and must therefore bear the burden of recreation-incurred injuries.

How is employer support and encouragement to be measured, in view of the varied administrative mechanisms used in recreational programs? A 1949 survey indicated that in over one-third of the plants surveyed administration of the recreation program was in the hands of a personnel department. ${ }^{21}$ Where the employer directly finances and administers the program granting recovery to the injured employees should pose no problem. ${ }^{22}$ However employee management, even if fictional, is recognized as a value ${ }^{23}$ and employee association administration is the most popular way of conducting recreational activities. Where the program is employee-managed, either through a distinct organization, or informally, the administrative mechanism should not be allowed to control or hide the extent of employer support.

Thus in Tedesco v. General Electric $\mathrm{Co}^{24}$ recovery was granted an employee member of the General Electric Athletic Association (GEAA) injured in a softball game under GEAA auspices. Although the recreation organization was a separate corporate entity in the hands of employees, the employer supplied grounds and facilities rent-free, subsizided operations and was represented on the GEAA board of directors. Publicity was allowed in the plant newspapers and solicitations were made on company time. ${ }^{25}$ Compensation was denied in a

"National Industrial Conference Board, Employee Recreation Activities, Studies in Personnel Policy No. 102 (1949) 15.

${ }^{22}$ Ott v. Industrial Commission, 83 Ohio App. 13, 82 N.E. 2d 137 (1948). Contra: Auerbach Co. v. Industrial Commission, 113 Utah 347, 195 P. 2d 245 (1948) (recovery denied where basketball playing was voluntary, although the employer paid for uniforms and team trips and a public relations officer conducted the over-all program).

${ }^{23}$ Consult authorities cited notes 9 and 10 supra.

24305 N.Y. 544, 114 N.E. 2d 33 (1953).

${ }^{25}$ Seemingly two added factors appear in Tedesco-the location of the activity on the employer's premises and the consequent power in the company to halt the program at any time. From a practical standpoint companies with large-scale recreation programs will and do use public facilities where they are available and convenient. The question of location of the activity should be of little significance in itself, except as it bears on the extent of the employer's control or his power to cut off the activity. See Petition for Writ of Error at 29, Jewel Tea Co. v. Industrial Comm'n, 6 Ill. 2d 304, 128 N.E. 2d 699 (1955). Emphasis on location as an independent factor, e.g., Wagner v. Buescher Band Instrument Co., 122 N.E. 2d 618 (Ind. App., 1954); McFarland v. St. Louis Car Co., 262 S.W. $2 d 344$ (Mo. App., 1953), stems partially at least from a confusion with the lunch-hour cases. Brown v. United Services for Air, 273 App. Div. 932, 78 N.Y.S. 2d 37 (3d Dep't, 1948); Geary v. Anaconda Copper Mining Co., 120 Mont., 485, 188 P. 2d 185 (1947); Thomas v. Proctor \& Gamble Mfg. Co., 104 Kan. 432, 179 Pac. 372 (1919).

In these cases injuries occurring during customary lunch-hour diversions on the employer's premises are compensated because of the physical connection of the injury with the employment and the employer's acquiescence in an established pattern of conduct, although there is no employer support or benefit. The rationale is similar to that of the "personal comfort" and "horseplay" cases note 2 supra, in which compensation is awarded, not because the employer seeks benefit, but because under the circumstances of the employment the acts are 
lower court $\mathrm{t}^{26}$ on the ground that the recreational organization was a separate corporate entity. The Court of Appeals, however, looked beneath the administrative structure, and, recognizing the nature of employer support and control, granted an award.

The administrative mechanism has in other cases hidden from the courts the attempts by the employer to promote the recreation program by giving the employees maximum control over it. For example, in Wagner v. Buescher Band Insirument $\mathrm{Co}^{27}$ recovery was denied where the employer did not directly lay down rules to an employee recreation association, although the association was partially financed by employer contributions and two management representatives sat on its board of directors.

Similarly in the Wilson case substantial employer support and encouragement were evidenced by the company supplying of uniforms and equipment, the appointment of a salaried foreman to supervise the league, and the allowing of meetings on company time. These evidences of support, extended as it must be presumed they were with an eye towards the resulting benefit, were overshadowed by the fact that the program was initially instituted by employees. In the Jewel decision these factors were correctly assessed. The employer was recognized as a moving party in spite of the fact that the program was begun by employees. The supplying of equipment, administrative aid and company publicity channels were recognized as the means through which the employer sought benefit.

If morale benefit is recognized as a real value which the employer seeks through institution or encouragement of a recreational program, it is incumbent upon the courts to look beyond the form of these programs. When not company-managed, the programs are actively kept in line with company policy through financial contributions, auditing of employee association accounts, employer representation on governing bodies, administrative aid through a staff member, and publicity through company channels. ${ }^{28}$ The presence of any of these factors in a given situation must be weighed as an indication of employer support, through which benefit is being sought. Such a program becomes an incident of the employment and is sufficiently work-connected to make the employer legally liable under the workmen's compensation formula.

reasonably to be expected. The lunch-hour criterion is sometimes confused with the support and benefit criterion, as in Luteran v. Ford Motor Co., 313 Mich. 487, 21 N.W. 2 d 825 (1946), in which an employee was injured during a ball game during a short lunch hour, where it was difficult to leave the premises, and the employer acquiesced in the custom of noon games. Recovery was denied on the ground that there was no employer support or resulting benefit.

${ }^{20} 276$ App. Div. 422, 95 N.Y.S. 2d 505 (3d Dep't, 1950), rev'd 305 N.Y. 544, 114 N.E. 2d 33 (1953).

${ }^{27} 122$ N.E. $2 d 618$ (Ind. App., 1954).

${ }^{28}$ National Industrial Conference Board, op. cit. supra note 21, at 29, 30. 